\title{
ANTIMICROBIAL PROPERTIES OF SCLEROTIORIN, ISOCHROMOPHILONE VI AND PENCOLIDE, METABOLITES FROM A BRAZILIAN CERRADO ISOLATE OF PENICILLIUM SCLEROTIORUM VAN BEYMA
}

\author{
Esther M.F. Lucas ${ }^{1}$; Mateus C. Monteiro de Castro ${ }^{1}$; Jacqueline A. Takahashi ${ }^{1 *}$ \\ ${ }^{1}$ Departamento de Química, Instituto de Ciências Exatas, Universidade Federal de Minas Gerais, Belo Horizonte, MG, Brasil
}

Submitted: March 23, 2007; Returned to authors for corrections: July 22, 2007; Approved: November 15, 2007.

\begin{abstract}
As a part of a research program that aims to identify antibacterial and antifungal substances from fungus specimen of Brazilian's cerrado soil samples, Penicillium sclerotiorum was identified as a source of secondary metabolites possessing antibiotic activities. This microorganism was cultured in a liquid medium rich in glucose for fifteen days. The resulting ethyl acetate extract was chemically fractionated leading to the isolation of three metabolites - pencolide, sclerotiorin and isochromophilone VI. The antimicrobial disc assay activity of these substances towards Candida albicans, Streptomyces pyogenes, Staphylococcus aureus, Salmonella typhimurium and Escherichia coli was performed. Minimum inhibitory concentration (MIC) of the compounds was determined. All compounds showed distinguished antimicrobial activities.
\end{abstract}

Key words: sclerotiorin, isocromophilone VI, pencolide, antibiotics, Penicillium sclerotiorum

\section{INTRODUCTION}

The discovery of penicillin and further development of antibiotic therapy was one of the most important achievements of last century. Novel antibiotics are nevertheless a real modern need, mainly for emergent economy countries where infectious sickness still causes a considerable number of deaths. The increasing amount of people who have imunossupressing or some metabolic diseases, the growing bacterial resistance phenomenon, the collateral effects of some antimicrobial drugs and the high cost of a complete and effective antimicrobial program contribute to this necessity.

Concerning that fungus versus fungus and fungus versus bacteria competition occurs based on chemical mediators, the research on new fungal metabolites that can became novel antibiotics prototypes is a very promising field (1). Fungi have proved to be capable of biosynthesizing secondary metabolites bearing conspicuous structural diversity, which could be further enlarged by structure modification. Among 20 of the most commonly prescribed medications, six are from fungal origin (2).
Brazilian cerrado transition biome holds a soil poor in nutritional compounds. To survive in hostile habitats it is expected that fungus isolated from cerrado transition areas should develop a sophisticated metabolism, most probably molecules of odd chemical structures possessing interesting biological properties.

Those facts motivated the development of a research program which aims to perform the isolation of antimicrobial substances from Brazilian's cerrado soil fungi. As a part of this program, three active compounds, pencolide (I) and the azaphilones sclerotiorin (II) and isochromophilone VI (III) were detected to be the active metabolites produced by $P$. sclerotiorum van Beyma (Fig. 1), one of the species isolated on this project.

Sclerotiorin (II) was the first fungal metabolite isolated from Penicillium sclerotiorum by Curtin and Reilly (3) and its structure was established by Dean in 1959 (4). Isochromophilone VI (III) was the first naturally occurring nitrogen-containing derivative from an azaphilone, isolated in 1995 (5), related to inhibit of cholesteryl ester transfer protein by two groups $(6,7)$. To sclerotiorin (II) there were related activities as endothelin receptor binding (8), inhibition of Grb-2-Sch interaction blocking the

*Corresponding Author. Mailing address: Departamento de Química - ICEx - UFMG - Av. Antonio Carlos, 6627, CEP 31270-901, Belo Horizonte, MG, Brasil. Tel.: +5531 3049-5754 - +5531 3049-5700. E-mail: jat@qui.ufmg.br 


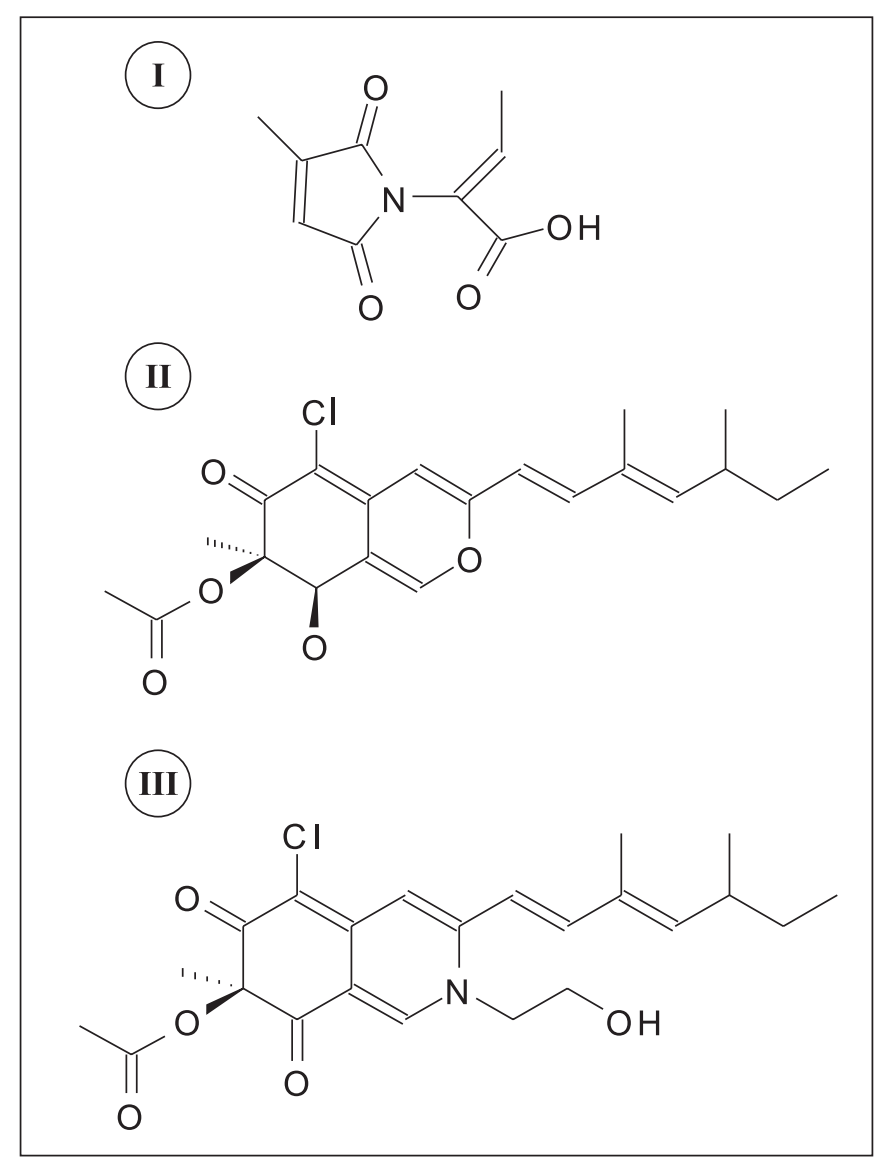

Figure 1. Chemical structures of pencolide (I), sclerotiorin (II) and isochromophilone VI (III).

oncogenic RAS signal (9), and inhibition of lipase leading to its patenting in Japan to prepare anti-acne creams and anti obesity biscuits (10). Sclerotiorin also inhibits aldose reductase, an enzyme associated to diabetics' complications such as cataract, neuropathy and nephropathy (11) and it has antibacterial activity in diffusion disc antibiotic test against Micrococcus luteus, Bacillus cereus, Bacillus subtilis, Klebisiella pneumoniae, Escherichia coli, Salmonella typhimurium and Lysteria monocytogenes (11). Pencolide (I) was also isolated from $P$. sclerotiorum and its structure was determinate chemically by Birkinshaw and co-workers (12) and spectroscopically by Sutherland (13). There were not found reports on pencolide biological activities.

The antimicrobial activity of substances I-III was evaluated against Candida albicans, Streptomyces pyogenes, Staphylococcus aureus, Salmonella typhimurium and Escherichia coli by qualitative disc test assay and the minimum inhibitory concentration (MIC) for antimicrobial activity was established.

\section{MATERIALS AND METHODS}

\section{Reagents and equipments}

Culture medium components were purchased from Biobrás (Montes Claros, Brazil). Solvents and eluants were purchased from Grupo Química (São Paulo, Brazil). Blanc and positive control discs were obtained from CECON (São Paulo, Brazil). Column grade silicagel (article 7734) and thin layer chromatography silicagel (article 7731) were purchased from Merck (Darmstadt, Germany). Vortex apparatus used was an AP 56-Phoenix (Araraquara, Brazil). Melting points were determined on a Mettler FP80HT apparatus and are uncorrected. Infrared spectra were obtained on a Spectrum One - FT - IR Spectrometer (Perkin-Elmer). ${ }^{1} \mathrm{H}$ and ${ }^{13} \mathrm{C}$ Nuclear Magnetic Resonance spectra were obtained from a Bruker DRX-400 and DRX 200 Advance. Mass spectra were obtained from a gas chromatographer HP5989A series II, coupled to a mass spectrometer 5989A HP, $70 \mathrm{eV}$ using a methyl silicone fusioned silica column $(30 \times 0.2 \mathrm{~mm})$.

\section{Microorganisms}

P. sclerotiorum was isolated from a soil sample collected at Serra do Cipó National Park Minas Gerais, a typical Brazilian region of cerrado transition. Small portions of soil were serially diluted and plated on solid media containing (g/l): $\mathrm{KH}_{2} \mathrm{PO}_{4}$ (1.0), $\mathrm{MgSO}_{4} .7 \mathrm{H}_{2} \mathrm{O}$ (0.5), Peptone (5.0), Dextrose (10.0), Rose Bengal (0.033). Upon growth, individual colonies were transferred to other plates successively until the isolation of pure cultures. $P$. sclerotiorum was identified by microscopic observation of micro-structure (14). The fungal strains were maintained on potato dextrose agar (PDA) and refrigerated at $7^{\circ} \mathrm{C}$. There were used the following American Type Culture Collection (ATCC) strains: Candida albicans ATCC 18804, Streptomyces pyogenes ATCC 19615, Staphylococcus aureus ATCC 29213, Salmonella typhimurium ATCC 14028 and Escherichia coli ATCC 25922.

\section{Metabolites production}

For metabolites production, P. sclerotiorum was inoculated into seven conical flasks, containing each, one liter of aqueous medium containing (g/l): Dextrose (20.0), Peptone (5.0), $\mathrm{KH}_{2} \mathrm{PO}_{4}$ (1.0), $\mathrm{MgSO}_{4} .7 \mathrm{H}_{2} \mathrm{O}(0.5)$ and $\mathrm{NaCl}(5.0)$. The growth took place for fifteen days, after which ethyl acetate was added to stop the growth.

\section{Extraction of metabolites}

The mycelium was separated from the culture broth by filtration. Both mycelium and broth of six conical flasks were extracted three times with $300 \mathrm{ml}$ of ethyl acetate each. The resulting layers were combined and the solvent was eliminated by evaporation by using a rotator vacuum distilling apparatus leading to $3.1 \mathrm{~g}$ of crude extract. 


\section{Isolation of pencolide (I) and isochromophilone VI (III)}

This extract was fractionated by chromatography in a silica gel column $(6.0 \times 25.0 \mathrm{~cm})$ using, as eluants, hexane, ethyl acetate and methanol $100 \%$ and in mixtures of growing polarities leading to 51 fractions, which were combined in 24 groups, according to thin layer chromatography profiles. Fractions 24-25, eluted by a mixture of hexane and ethyl acetate 1:3 were joined leading to $569 \mathrm{mg}$ of a brown solid that, after being washed with ethyl ether lead to $33.1 \mathrm{mg}$ of a white solid that was identified as pencolide (I). Fractions 33-42 were also combined, leading to the isolation of $29.7 \mathrm{mg}$ of a solid that was rechromatographed on a silica gel column $(2.0 \times 5.5 \mathrm{~cm})$ eluted as before. Fractions $34-51$, eluted by a mixture of hexane and ethyl acetate $1: 1$ gave $32.9 \mathrm{mg}$ of a red solid that was isolated and identified as isochromophilone VI(III).

\section{Isolation of sclerotiorin (II)}

To the culture medium of one conical flask $300 \mathrm{ml}$ of ethyl acetate were added and this system was left standing at room temperature for 24 hours. After this time, the natural evaporation of ethyl acetate lead to precipitation of a dark orange solid, that was collected and washed successively with ethyl alcohol at room temperature then under heating and with heated hexane, leading to $7.6 \mathrm{mg}$ of an orange solid that was identified as sclerotiorin (II).

\section{Identification of the substances}

Identification of the substances was performed by the comparison of the measured melting points and spectral data with those described on the literature $(7,12,13$ and 15).

\section{Antimicrobial activity assay}

$2.0 \mathrm{mg}$ of each substance were solubilized in $1 \mathrm{ml}$ of chloroform. $50 \mu \mathrm{l}$ of each solution were quantitatively loaded on a paper to make a final concentration of $100 \mu \mathrm{l} / \mathrm{disc}$. The solvent was removed by dry air. The test plates were prepared with 7.5 $\mathrm{ml}$ of Number 1 Antibiotic Medium and sterilized in autoclave by 15 minutes at $121^{\circ} \mathrm{C} .0 .4 \mathrm{ml}$ of the diluted bacteria inoculum $(500$ $\mu \mathrm{l}$ of stock culture in $2.0 \mathrm{ml}$ of $\mathrm{BHI}$ let $18 \mathrm{~h}$ at $37^{\circ} \mathrm{C}$ ) were transferred to $4.5 \mathrm{ml}$ of saline solution) and homogenized using a vortex. A negative control was set using a disc impregnated with $50 \mu \mathrm{l}$ of chloroform, and chloramphenicol (30 $\mu \mathrm{g} / \mathrm{disc})$ was used as positive control of antibacterial test; to antifungal test miconazol $(50 \mu \mathrm{g} / \mathrm{disc})$ was used. Experiments were run in duplicate. The result was ridden after incubation by 24 hours at $37^{\circ} \mathrm{C}$.

\section{Minimum inhibitory concentration test}

$2.05 \mathrm{mg}$ of each test substance were dissolved in $2.0 \mathrm{ml}$ of dimetylformamide. The minimum inhibitory concentration test of substances 1-3 were determined by series dilution in BHI on the concentrations of 512, 256, 128, 64, 32, 16, 9, 4, 2 and 1 $\mu \mathrm{g} / \mathrm{ml}$. Aliquots of $100 \mu \mathrm{l}$ of the bacteria suspensions, which had their concentrations adjusted according to $0.5 \mathrm{McF}$ arland scale $\left(1.5 \times 10^{8} \mathrm{CFU} / \mathrm{ml}\right)$, were added to tubes containing $1 \mathrm{ml}$ of BHI medium plus the test substances. Test tubes were incubated by 24 hours, at $37^{\circ} \mathrm{C}$, and the minimum inhibitory concentration was determined as the lowest concentration of substance that showed no haze. Both assays were carried out in duplicate.

\section{Survival microorganism test}

$50 \mathrm{ml}$ of each end point test tube solution were transferred to a tube containing $2.0 \mathrm{ml}$ of $\mathrm{BHI}$ and incubated by 24 hours, at $37^{\circ} \mathrm{C}$. When no haze was observed, the effect of the substance was considered to be bactericidal and, those ones where haze was observed, a bacteriostatic effect of the substance was characterized.

\section{RESULTS AND DISCUSSION}

From all fungi isolated from Serra do Cipó National Park soil, P. sclerotiorum showed to be one of the most active isolates. Large scale liquid culture of this species led to the isolation of pencolide (I), sclerotiorin (II) and isochromophilone VI (III). As sclerotiorin has been previously reported to be an antibacterial agent (11), compounds I and III were screened by disc diffusion test in order to observe wheatear they also contributed for the extract bioactivity. Sclerotiorin was included in the bioactivity study in order to broader its antibacterial screening. In the disc test, compounds I and II showed inhibition zones towards all Gram positive and Gram negative bacteria tested (S. pyogenes, S. aureus, S. typhimurium and E. coli) and towards the yeast $C$. albicans. Isochromophilone VI (III) showed inhibition zone only against $S$. aureus. The values of inhibition zones are shown on Table 1. Despite its simple structure compared to sclerotiorin and isochromophilone VI, pencolide showed to be most active tested metabolite of $P$. sclerotiorum. The inhibition zone values of all compounds are lower than the values observed for the positive controls. However, considering the low diffusion rate of non-polar compounds in agar, such results are still promising.

For a more quantitative comparison of potential of compounds I-III as new leads for the development of antibiotic agents, minimum inhibitory concentration of all compounds was evaluated. Results obtained for sclerotiorin (II) against $E$. coli and $S$. typhimurium are in accordance with the activity reported for this compound by Chidananda and co-workers (11), but, in our experiments, compound II showed activity also against $S$. aureus, probably due to the use of a different bacterial strain (16). The MIC and survival test results confirm the activity of sclerotiorin (II) against $S$. aureus (Table 2) in our screening protocol.

Interestingly, isochromophilone VI (III) did not show activity in the disc diffusion assay against S. pyogenes, S. typhimurium, 
Table 1. Diameter of inhibition zones ( $\mathrm{mm})$ of tested substances on disc diffusion test.

\begin{tabular}{ccccc}
\hline \multirow{2}{*}{$\begin{array}{c}\text { Pathogenic } \\
\text { microorganism }\end{array}$} & \multicolumn{3}{c}{ Diameter of inhibition zone (mm) } \\
\cline { 2 - 5 } & Pencolide (I) & Sclerotiorin (II) & Isochromophilone VI (III) & Control* \\
\hline S. pyogenes & $15.50 \pm 0.05$ & $10.50 \pm 0.09$ & $(\underline{\mathrm{a}})$ & $30.00 \pm 0.01$ \\
S. aureus & $12.50 \pm 0.01$ & $10.50 \pm 0.08$ & $10.00 \pm 0.40$ & $18.50 \pm 0.02$ \\
S. typhimurium & $16.75 \pm 0.03$ & $13.00 \pm 0.40$ & $(\underline{\mathrm{a}})$ & $22.00 \pm 1.00$ \\
E. coli & $12.50 \pm 0.00$ & $12.00 \pm 0.01$ & $(\underline{\mathrm{a}})$ & $18.50 \pm 0.01$ \\
C. albicans & $13.05 \pm 0.09$ & $13.00 \pm 0.00$ & & $20.50 \pm 0.10$ \\
\hline
\end{tabular}

* Control: miconazol (C. albicans); chloramphenicol (bacteria);

(a): absence of inhibition zone.

Table 2. Minimum inhibitory concentration of the test substances upon pathogenic microorganisms and survival test result

\begin{tabular}{|c|c|c|c|c|}
\hline $\begin{array}{l}\text { Pathogenic } \\
\text { microorganism }\end{array}$ & \multicolumn{4}{|c|}{ MIC $(\mu \mathrm{g}) /$ Type of antimicrobial activity } \\
\hline S. pyogenes & $128 / \mathrm{Bs}$ & $128 / \mathrm{Bs}$ & 64/Bs & 32 \\
\hline S. aureus & $128 / \mathrm{Bs}$ & $128 / \mathrm{Bs}$ & $128 / \mathrm{Bs}$ & 32 \\
\hline S. typhimurium & $128 / \mathrm{Bs}$ & $128 / \mathrm{Bs}$ & $64 / \mathrm{Bs}$ & 4 \\
\hline E. coli & $128 / \mathrm{Bs}$ & $128 / \mathrm{Bs}$ & $64 / \mathrm{Bs}$ & 4 \\
\hline
\end{tabular}

* Control: miconazol (C. albicans); cloranfenicol (bacteria);

$\mathrm{Bs}=$ bacteriostatic $; \mathrm{Fc}=$ fungicidal $; \mathrm{Fs}=$ fungistatic .

E. coli and C. albicans, but presented activity at low doses (64 $\mathrm{mg}$ ) in the MIC tests. This is indeed a good indication that disc diffusion assay should be considered only a very preliminary screening test, with serious limitation when organic non polar compounds are screened. Several factors besides diffusion rate in solid agar media can hold up linearity between inhibition zone diameter and antibiotic activity of a given compound, for example, amount of substrate loaded in the disc, precipitation of the compound on the disc after solvent evaporation, residual solvent content in the disc (especially when non volatile solvents such as dimethylsulphoxide are used), full adherence of the paper disc on the agar surface and size of the inoculum used in the experiment. Upon a careful observation of such possible interferences, disc diffusion assay is still a useful tool for preliminary screening on natural products bioprospecting programs.

When the kind of bacterial growth activity presented by pencolide, sclerotiorin and Isochromophilone VI was studied, it was found that they possess bacteriostatic activity against all Gram positive and Gram negative bacteria tested, suggesting a possible broad activity spectrum. The low MIC values obtained for isocromophilone VI suggests a more effective activity of this substance against $S$. pyogenes and $S$. typhimurium than the other two compounds.

The fungicidal activity against $C$. albicans was observed for all tested substances. This result is quite interesting due to the increasing problems faced by patients bearing C. albicans recurrent infections. This yeast is also the main causative agent of a frequent oropharyngeal candidiasis in immune deficient patients (17) and it is pretty difficult to find substances active against $C$. albicans bearing selective toxicity, due the resemblance between mammalian and fungal cells. The existence of a Japanese patent on the use of extracts rich in sclerotiorin in food preparations (10) points out that the use of this substance to combat human fungal infections may not cause toxic collateral effects.

\section{ACKNOWLEDGMENTS}

The authors thank International Foundation for Science (IFS, grants F/3564-1 and 2), Conselho Nacional de Desenvolvimento Científico e Tecnológico (CNPq, Process 307846/2006-7) and Fundação de Amparo à Pesquisa do Estado de Minas Gerais (FAPEMIG, grant CEX 1088/05) for financial support. 


\section{RESUMO}

\section{Atividade antimicrobiana de esclerotiorina, isocromofilona VI e pencolídeo, metabólitos secundários de Penicillium sclerotiorum van Beyma isolado de solo do cerrado brasileiro}

Como parte de um programa de pesquisa visando a identificação de substâncias antibacterianas e antifúngicas a partir de espécies fúngicas isoladas de solo do cerrado, foi estudado o fungo Penicillium sclerotiorum van Beyma. Este microrganismo foi cultivado em meio líquido rico em glicose e, após extração com acetato de etila, este foi quimicamente fracionado levando ao isolamento de três metabólitos pencolídeo, esclerotiorina e isocromofilona VI. A atividade destas três substâncias, por meio de teste de difusão em discos, contra Candida albicans, Streptomyces pyogenes, Staphylococcus aureus, Salmonella typhimurium e Escherichia coli foi avaliada. A concentração inibitória mínina das substâncias ativas foi determinada.

Palavras chave: esclerotiorina, isocromofilona VI, pencolídeo, antibióticos, Penicillium sclerotiorum

\section{REFERENCES}

1. Newman, D.J.; Cragg, G.M. (2007) Natural Products as Sources of New Drugs over the Last 25 Years. J. Nat. Prod., 70(3), 461-477.

2. Furtado, N.A.J.C.; Fonseca, M.J.V.; Bastos, J. (2005). The potential of an Aspergillus fumigatus Brazilian strain to produce antimicrobial secondary metabolites. Braz. J. Microbiol., 36, 357-362.

3. Curtin, T.M.; Reilly, J. (1940). Sclerotiorin, a chlorinated metabolic product of Penicillium sclerotiorum, Van Beyma. Nature, 3697 335.

4. Dean, F.M.; Staunton, J.; Waalley, W.B. (1959). The chemistry of fungi. Part XXXVI. A revised structure for sclerotiorin. J. Chem. Soc., 3004-3009.
5. Wei, W-G.; Yao, Z-J. (2005). Synthesis studies toward Chloroalzaphilone and Vinylogous-pyridones: Two common Natural product core structures. J. Org. Chem., 70, 4585-4590.

6. Arai, N.; Shiomi, K.; Tomoda, H.; Tabata, N.; Yang, D.J.; Masuma, R.; Kawakubo, T.; Omura, S.J. (1995). Isocromophilones I-VI, inihibitors off acyl-CoA: cholesterol transferase produced by Penicillium multicolor FO-3216. The J. of Antib., 48(7), 696-702.

7. Tomoda, H.; Matsushima, C.; Tabata, N.; Namatame I; Tanaka, H. Bamberger M. J.; Arai H.; Fukazawa M.; Inoue K.; Omura, S. J. (1999). Stucture-specific inihibition of: cholesteryl ester transfer proteins by Azaphilones. The J.of Antib., 52(2), 160-170.

8. Pairet, 1.; Wrigley, S.K.; Chetland, I,; Reynolds, E.E.; Hayes, M.A. Holloway, J.; Ainsworth, A.M.; Katzer, W.; Cheng, X-M.; Hupe, D.J.; Charlton, P.; Doherty, A.M. (1995). Azaphilones with endothelin receptor biding activity produced by Penicillium sclerotiorum taxonomy, fermentation, isolation, structure elucidation and biological activity. The J. of Antib., 48(9), 913-922.

9. Nam, J-Y.; Kwang-Hee, S.; Hyae-Kyeong K.; Mi-Young, H.; SungUk, K.; Jung-Do, C.; Byoung-Mog, K. (2000). Sclerotiorin and Isocromophilone IV: inhibitors of Grb2Shc interaction, isolated from Penicillium multicolor F1753. J. Microbiol. Biotechnol., 10(4), 544546.

10. Negishi, Y.; Matsuo, N.; Miyadera, K.; Tanishima, M. (2000). Lipase inhibitors containing sclerotiorin. Jpn. Pat., 98-376263 19981224.

11. Chidananda, C.; Rao, J.M.; Sattur, A.P. (2006). Sclerotiorin, from Penicillium frequentans, a potent inhibitor of aldose reductase. Biotechnol. Lett., 28, 1633-1636.

12. Birkinshaw, J.H.; Kalyanpur, M.G.; Stickings, C.E. (1963). Studies in the biochemistry of micro-organisms. Biochem. J., 86, 237-243.

13. Sutherland J.K. (1963). The proton-Magnetic-Resonance spectrum of pencolide. Biochem. J., 86, 243

14. Pitt, J. (2000). A Laboratory guide to common Penicillium species. Food Science, Australia, 197p

15. Michael, A.P.; Grace, E.J.; Kotiw, M.; Barrow, R.A. (2003) Isochromophilone $\mathrm{XI}$, a novel GABA-containing metabolite isolated from a cultured fungus Penicillium sp. Aust. J. Chem., 56(1), 13-15.

16. Indu, M.N.; Hatha, A.A.M.; Abiroshi, C.; Harsha, U.; Vivekanandan, G (2006). Antimicrobial activity of some of the south-indian species against serotypes of Escherichia coli, Salmonella, Listeria monocitogenes and Aeromonas hidrophila. Braz. J. Microbiol., 37, 153-158.

17. Melo, N.R.; Vilela, M.M.S.; Junior, J.J.; Kamei, K.; Miayaji, K.F.; Nishimura, K.; Groeneveld, P.; Kelly, S.; Taguchi, H. (2006). HIV-1 anti-retroviral drug effect on the $C$. albicans hyphal growth rate by a bio-cell tracer system. Braz. J. Microbiol., 37, 225-229. 